\title{
A Study on Gimbal Mechanism for AMB-Flywheel Energy Storage System of Electric Vehicle
}

\author{
島崎 浩（千葉大）＼cjkstart野波 健蔵（千葉大）
}

Hiroshi SHIMAZAKI, Chiba University, Yayoi 1-33, Inage-ku, Chiba 263-8522

Kenzo NONAMI, Chiba University

This paper deals an electric vehicle with flywheel energy storage system using active magnetic bearings (AMBs) and gimbal. At first the equation of motion of a flywheel energy storage system using active magnetic bearings and gimbal. This equation of motion is a strong nonlinear equation. So, the approximated linear equation of motion is derived and the usefulness of this approximated equation is made sure by experiments and simulation. The spring constant of gimbal mechanism influences the natural frequencies. The best design of gimbal should be extreme low natural frequency of gimbal. Finally, the ideal gimbal design method is proposed.

Key words: active magnetic bearing, flywheel energy storage system, electric vehicle, gimbal design

\section{A 1.はじめに}

エネルギーの有効利用法の一つとして電力貯蔵型磁気軸受 フライホイールが注目されている.フライホイールは円盤に 回転軸を取り付けたもので回転軸を回転させることで電力を 回転（力学的）エネルギーとして貯蔵する力学的な電力貯蔵 装置である. 電力を貯蔵する際には適当なエネルギー変換装 置, 例えばモータなどを通してフライホイールの回転速度を 増大することにより行い，電力を取り出す際には再びエネル ギー変換装置を通してフライホイールの回転速度を減少させ ることにより行う。そのため電力貯蔵型フライホイールは従 来の蓄電池に比べ充電に要する時間が少なく, 充電・放電の 忘答にも優れており高効率のエネルギ一変換効率が期待され ている．また，鈶蓄電池のように鉛などの有害物質を使用し ないため環境に優しい電力貯蔵装置としても注目されている. さらに磁気軸受フライホイールは軸受部分に設置した電磁石 の磁気吸引力を制御することで回転軸を非接触支持すること ができるため, 摩擦や磨耗などがない. そのため潤滑や粉微 塵の心配がなく, 軸受の寿命は半永久的で部品交換などの定 期的なメンテナンスを必要としない。 また，潤滑油を使用し ないため, 真空環境や超低温環境下での運転が可能であり, エネルギー損失は極めて少ない.このような長所から電力貯 蔵型フライホイールは鉄道や発電所, 補助電源無停電電 源装置としての利用が実用化されている.

ジンバル機構は直行する $2 つ の$ 傾斜軸を組み合わせること で任意の方向に傾斜できる機構である.フライホイールを車
両に搭載する際にジンバル機構と組み合わせて搭載すること で，車両の姿勢変動によらずフライホイールは回転の姿勢を 一定に保つことができる. そのため走行中におけるフライホ イールの回転軸にかかる軸荷重（ジャイロモーメント）を低 減化することができる. しかし，ジンバル機構の軸受部分で の摩擦や回転中心と質量中心のずれが存在することで, 車両 の走行中において僅かなモーメントが生じ，ジンバルは回転 運動を始めてしまう. ジンバル機構には復元力を生じる要素 がないため, ジンバルに変位を制限させるための要素が必要 となる. 図A1はジンバル機構におもりを付加したもので, 振 子として作用させることで重力による復元力を利用するもの である。

本研究では, 振子型ジンバル機構を有する磁気軸受フライ ホイールの動力学的特性を明らかにするとともに, ジンバル 機構の設計パラメータに関する考察を行う。そして, ジンバ ルを最適に設計するための方法について考察している．

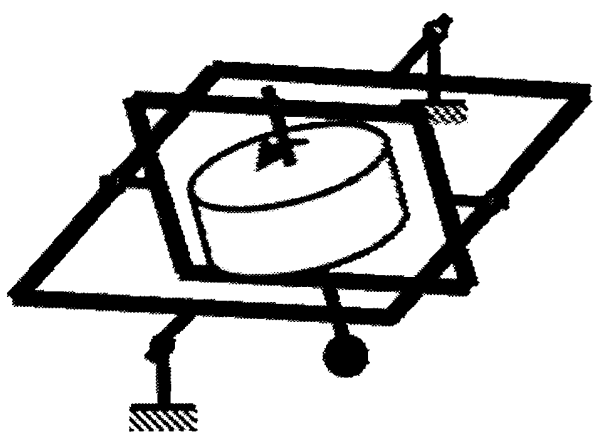

Fig. A1 Pendulum type gimbal mechanism 
1. 振子型ジンバル機構を有する磁気軸受フライホイール のモデリング

本章では振子型ジンバル機構を有する磁気軸受フライホイ 一ルの動力学的特性を明らかにするために運動モデルの導出 を行う。図 1 に振子型ジンバル機構を有する磁気軸受フライ ホイールの運動モデルの模式図を示す．解析モデル導出には 表1に示す記号を使用し, 以下の仮定を行う. (1)フライホイー ルとジンバルを組み合わせたときの運動はジンバルの回転中 心に拘束されるものとする. (2)フライホイールの質量中心は, ジンバルの回転中心を原点とする軸上にあるものとする． (3) ジンバル機構の軸受部分での摩擦は，粘性摩擦としてモデル 化を行う。(4)フライホイールの回転角は小さいとして微少近 似する. (5)フライホイールの回転速度は一定とし, 空気抵抗 などの損失は無視する.

ジンバル機構を有する磁気軸受フライホイールの非線形 解析モデルは次式のように得られる.

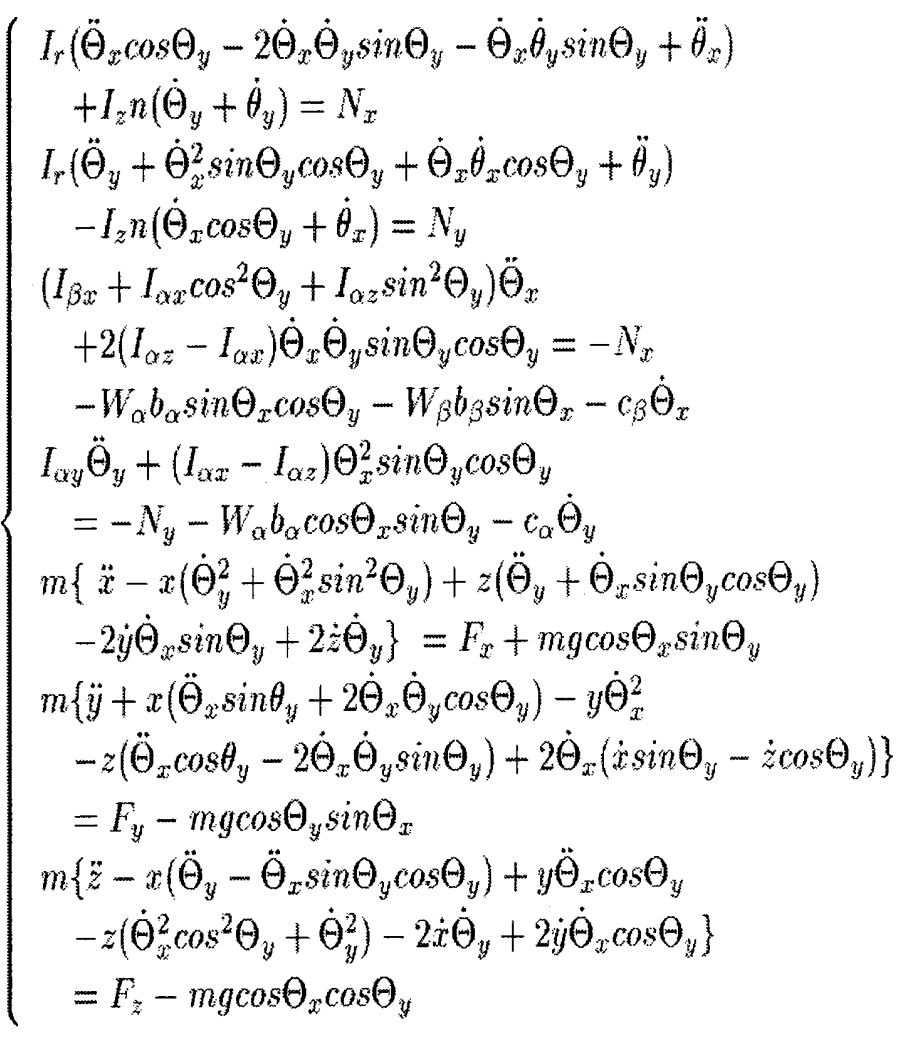

上記のモデルは非線形微分方程式であり一般に解析が困難 であるため，原点近傍での線形近似モデルを導出する．ジン バル $\alpha$ ジンバル $\beta$ の振れ角 $\theta \mathrm{y}, \theta \mathrm{x}$ もさらに微少であると 仮定し, 得られた非線形解析モデルの1次近似線形化を行う. この結果，以下の線形モデルが得られる.

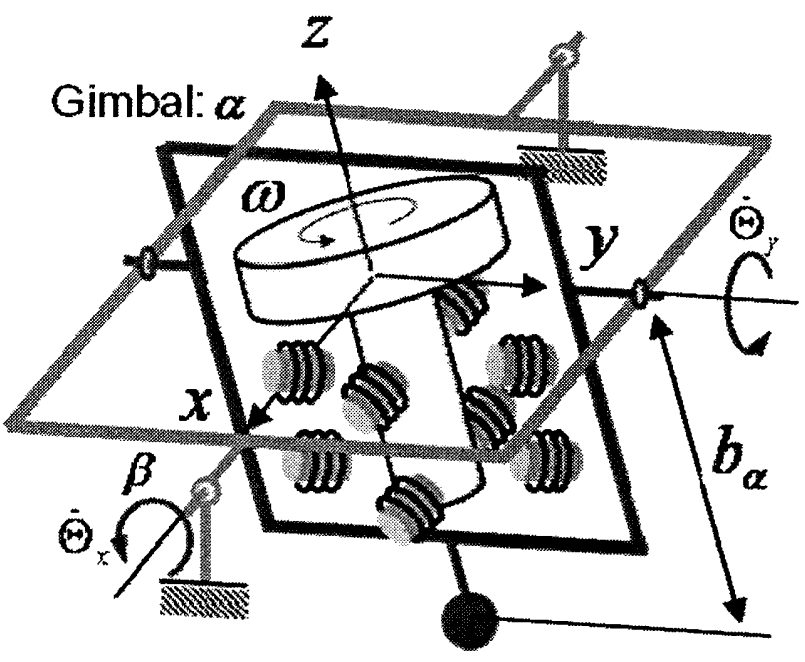

Fig. 1 Simplified model of AMB-FW with gimbal

Table 1 Nomenclature of modeling of AMB-FW with gimbal

\begin{tabular}{|c|c|}
\hline Parameter & Signification \\
\hline $\mathrm{m}$ & Mass of flywhes \\
\hline$I_{\mathrm{r}}$ & Moment of inertia for fywheel \\
\hline$I_{z}$ & Polar moment of inertia lor fywheet \\
\hline$\omega$ & Rotation speed of flywheel \\
\hline$x, y$ & Position of flywheal $\mathrm{C} . \mathrm{G}$. \\
\hline$\theta_{x}, \theta_{3}$ & Rotation angle of $x$-axis $y$-axis of flywhed \\
\hline$\delta$ & Distance between geometrical center \\
\hline & and $C . C^{*}$ \\
\hline$l_{x}$ & Distance betwon coordinate origh and \\
\hline & geometrical center \\
\hline$f_{x x x}, f_{x i}, f_{3 n}, f_{y}^{k}$ & Magnetic attractive force \\
\hline$W_{\alpha}$ & Weight of inner gimbal \\
\hline$b_{\alpha}$ & Distance from inuer gimbal axis to C.G. \\
\hline$f_{x x: \xi} l_{x y y}, l_{\alpha x:}$ & Moment of inertia for inner gimbal \\
\hline$\varepsilon_{\alpha}$ & Darnping const. for inner gimbal \\
\hline$\Theta_{3}$ & Rotation angle of inner gimbal \\
\hline$W_{3}$ & Weight of outer gimbal \\
\hline$b_{3}$ & Distance from outer gimbal axis to $\mathrm{C} G$. \\
\hline$I_{\beta x}, I_{g_{x}}, I_{g *}$ & Noment of inertia for outer gimbal \\
\hline$c_{\beta}$ & Damping const for onter gimbal \\
\hline$\Theta_{x}$ & Rotation angle of outer gimbal \\
\hline
\end{tabular}




\section{2．実験によるモデルの妥当性の検証}

\section{1 固有值による検証}

前節で導出した式 (2) の線形モデルの妥当性について検証 を行った. 最初にフライホイールの回転速度の変化に対する 固有振動数の変化について導出した線形モデルと実機との比 較を行った．図2 に線形モデルと実機により測定した固有振 動数の変化を示す．図2（b）は低周波数領域に対して拡大し たものである．図中の実線は線形モデルの固有振動数の変化 であり，○は実機の測定結果をプロットしたものである. 図2 よりおおよその傾向として導出した線形モデルと実機による 測定結果との間に適合性が見られるのが確認できる.ただし， 高周波数の固有振動数に関してはモデルの導出の際には考慮 していない弾性モードが表れるため比較の対象とはしなかっ た。これより，導出した線形モデルはフライホイールの回転 速度の変化に対する固有振動数の変化という点において妥当 であることが確認できた。

\section{2 時刻歷応答による検証}

次に外乱を与えたときの力学的挙動について導出した線形 モデルと実機との比較を行った. フライホイールの回転速度 が $0 \mathrm{~Hz}, 50 \mathrm{~Hz}, 100 \mathrm{~Hz}$ において，ジンバル $\beta$ に対して $-1.96 \mathrm{Nm}$ の ステップ外乱を与えた。なお，実機でのステップ外乱はジン バル機構におもりを付加することによって与えた．フライホ イールの非接触制御は共にPD制御器によって制御している. 図3に実機による応答結果を，図4にシミュレーション結果を 示す. 図3と図4は100Hzでロータが回転中にステップ外乱を印 加した際のフライホイールの変位の時刻歴応答，および，ジ ンバルの時刻歴応答を示している. なお，シミュレーション モデルにおけるパラメータは実測から求めている。これより 導出した線形モデルと実機によるフライホイール及びジンバ ルの挙動や周波数に関して適合性が見られるのが確認できる。 しかし，減衰特性に関しては実機の方が収束が早く，半周期 程度で収束してしまった。これは実機ではジンバル機構の軸 受部分でのクーロン摩擦や静止摩擦の影響を強く受けたもの であると考えられる。モデルの導出では軸受部分での摩擦を 粘性摩擦として仮定したが実際の摩擦はクーロン摩擦や静止 摩擦である。粘性摩擦は速度に比例して粘性力が大きくなる が，ジンバルの歳差運動のように低周波振動に対しては粘性 摩擦の影響は小さくなってしまう。一方，クーロン摩擦は速 度の大きさに依存せず符号によって決まり，大きさは一定で

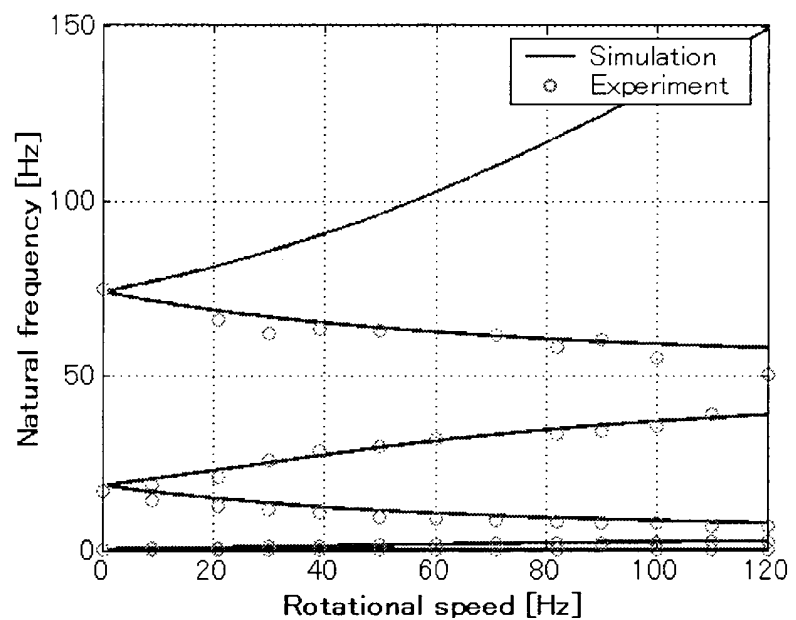

(a) Over-all view

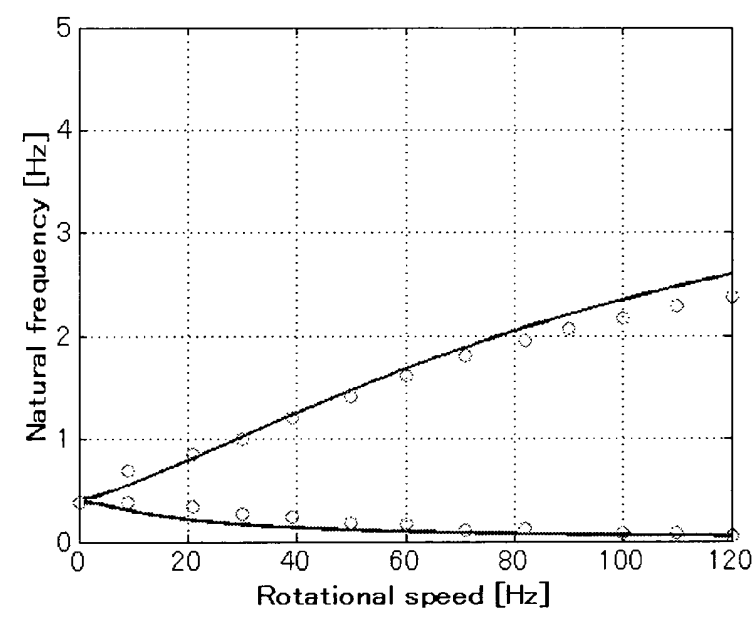

(b) Enlarged view at low frequency region

Fig. 2 Natural frequency VS. rotational speed

ある.また, 静止摩擦は低速度であるほど影響を受けやすい， このことからフライホイールの回転速度が大きくなった場合 はクーロン摩擦や静止摩擦に大きく影響してまったと考えら れる。しかし，これらの摩擦は実際にはジンバルの不安定化 を抑制する方向に作用するため，設計の段階では特に考慮す る必要性がないと考えられる，以上より，固有值の変化およ び力学的挙動について実機との比較を行った結果, パラメー 夕誤差や摩擦などの影響による差異はあるが，モデルの構造 として妥当であることが確認できた．次章では導出した線形 モデルを用いてジンバル機構の設計パラメータに関する考察 を行う。

2. ジンバル機構の設計パラメータに関する考察

2.1 設計パラメータに関する数值的考察

車載用（加速環境下）に適した理想的な振子型ジンバル機 


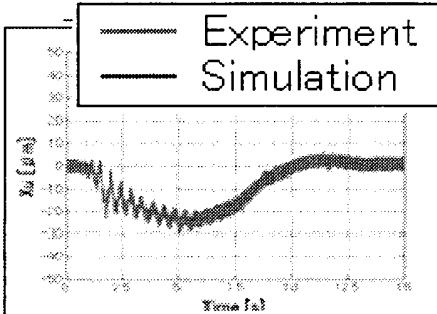

Displacement of $\times u$

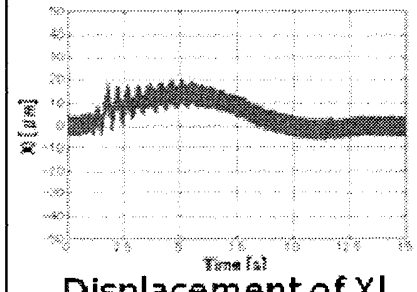

Displacement of XI

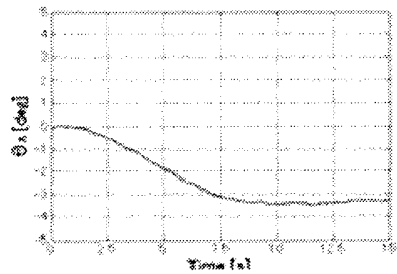

Displacement of $\Theta x$

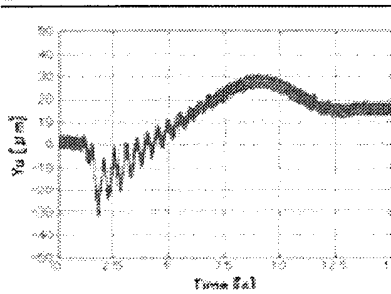

Displacement of $\mathrm{Yu}$

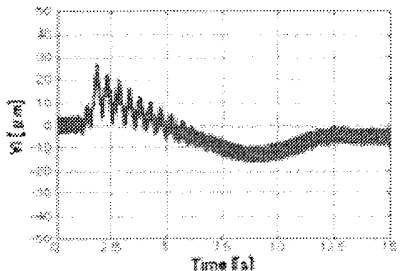

Displacement of $Y \mathrm{I}$

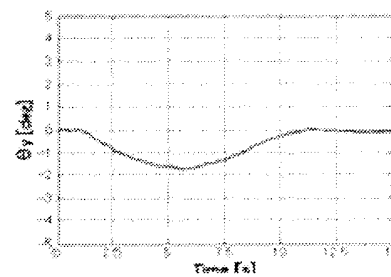

Displacement of $\Theta y$

Fig. 3 Experimental results against step disturbance (Rotational speed of Flywheel:100Hz)

構の設計パラメータについて考察する.ここではジンバルの 慣性モーメント, 粘性係数, 重力による復元係数を変化させ たときのフライホイールおよびジンバルの挙動について考察 する。

表 2 に振子型ジンバル機構の設計パラメータ例を示す. Case Aは現システムを参考にしたパラメータであり, Case B はCase Aの慣性モーメントを2倍にしたもの, Case Cは粘性係 数を2倍したもの, Case Dは復元係数を1/2倍したものである.

これらの設計パラメータの変化はジンバル機構の固有振動振 動数（または減衰固有振動数）が低くなるように設定した. その理由は固有振動数を低くすることでジャイロモーメント による軸荷重を低减できるためである，また，短時間（有限 時間）で行われる加速運動に対してはジンバル機構の（歳差 運動の）固有振動数を低くした方がジンバル機構の変位が抑 えられると考えたためである.

表2の設計パラメータに対して車両の走行を模擬したシミ ユレーションを行う. 加速環境下におけるジンバル機構を有 する磁気軸受フライホイールの運動方程式は慣性抵抗を付加 した次式で表せる（図5参照）。それぞれの設計パラメータに 対して, フライホイールの回転数が $200 \mathrm{~Hz}$ のとに加速度外 乱を与えたときのフライホイール及びジンバル機構の忍答結

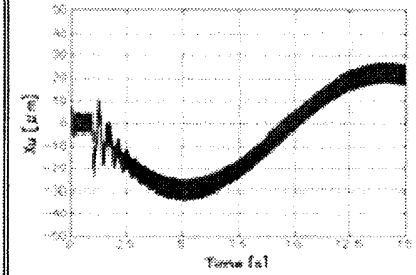

Displacement of $\mathrm{Xu}$

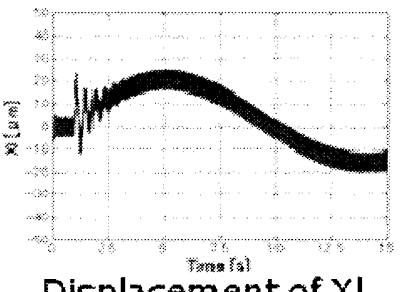

Displacement of XI

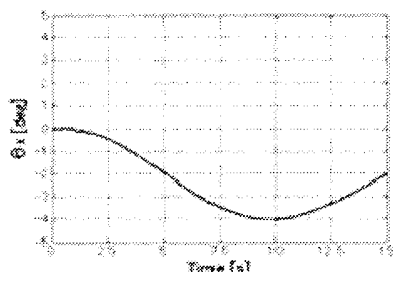

Displacement of $\Theta x$

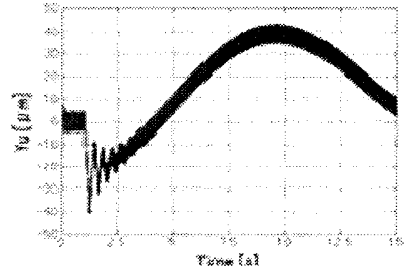

Displacement of $\mathrm{Yu}$

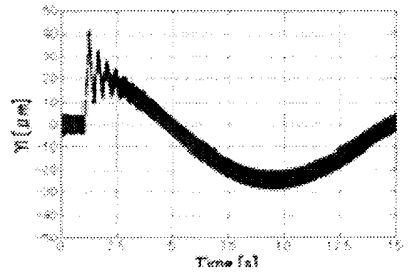

Displacement of $\mathrm{YI}$

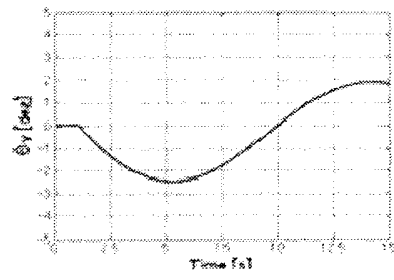

Displacement of $\Theta y$
Fig. 4 Simulated results against step disturbance (Rotational speed of Flywheel:100Hz)

Table 2 Physical parameters of gimbal

\begin{tabular}{|c|c|c|c|c|}
\hline Parameter & Case A & Case B & Case C & Case D \\
\hline$I_{\alpha x}\left[\mathrm{Kg} \cdot \mathrm{m}^{2}\right]$ & 4.48 & 8.87 & 4.48 & 4.48 \\
$I_{\alpha y}\left[\mathrm{Kg} \cdot \mathrm{m}^{2}\right]$ & 4.48 & 8.87 & 4.48 & 4.48 \\
$I_{\beta x}\left[\mathrm{Kg} \cdot \mathrm{m}^{2}\right]$ & 0.62 & 1.24 & 0.62 & 0.62 \\
$I_{\beta y}\left[\mathrm{Kg} \cdot \mathrm{m}^{2}\right]$ & 0.62 & 1.24 & 0.62 & 0.62 \\
$c_{\alpha}[\mathrm{N} \cdot \mathrm{m} \cdot \mathrm{s} / \mathrm{rad}]$ & 6.0 & 6.0 & 12.0 & 6.0 \\
$c_{\beta}[\mathrm{N} \cdot \mathrm{m} \cdot \mathrm{s} / \mathrm{rad}]$ & 12.0 & 12.0 & 24.0 & 12.0 \\
$k_{\alpha}[\mathrm{N} \cdot \mathrm{m} / \mathrm{rad}]$ & 28.0 & 28.0 & 28.0 & 14.0 \\
$k_{\beta}[\mathrm{N} \cdot \mathrm{m} / \mathrm{rad}]$ & 44.0 & 44.0 & 44.0 & 22.0 \\
\hline
\end{tabular}

$$
\left\{\begin{array}{l}
I_{r} \ddot{\theta}_{x}+I_{z} n \dot{\theta}_{y}=N_{x}-I_{r} \ddot{\Theta}_{x}-I_{z} n \dot{\Theta}_{y} \\
I_{r} \ddot{\theta}_{y}-I_{z} n \dot{\theta}_{x}=N_{y}-I_{r} \ddot{\Theta}_{y}+I_{z} n \dot{\Theta}_{x} \\
\left(I_{\alpha x}+I_{\beta x}\right) \ddot{\Theta}_{x}+c_{\beta} \dot{\Theta}_{x}+k_{\beta} \Theta_{x}=-N_{x}-\frac{k_{s}}{g} a_{y} \\
I_{\alpha y} \ddot{\Theta}_{y}+c_{\alpha x} \dot{\Theta}_{y}+k_{\alpha} \Theta_{y}=-N_{y}+\frac{k_{\alpha}}{g} a_{x} \\
m \ddot{x}=F_{x}+m g \Theta_{y}-m a_{x} \\
m \ddot{y}=F_{y}-m g \Theta_{x}-m a_{y}
\end{array}\right.
$$

果を，図6と図7に示す．図6はCase Aの場合で, Case B, Case Cのいずれも同様な結果であった，図6の結果から軸の軌跡は $100 \mu \mathrm{m}$ を越える振動となっておりタッチダウンすることがわ かる.この原因は低周波数の振動に起因しており，ジンバル 


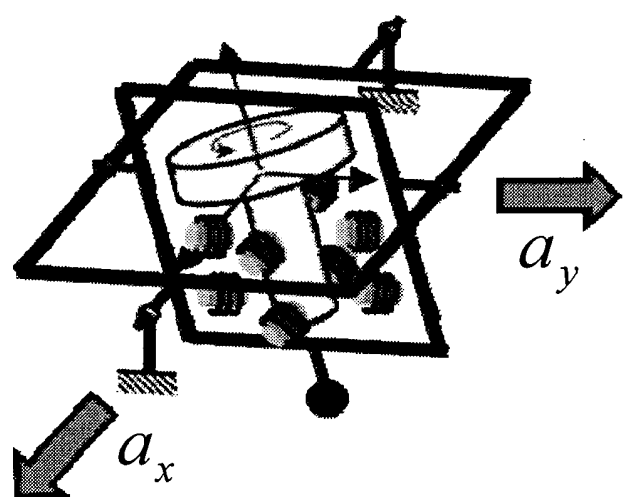

Fig. 5 Disturbance direction of acceleration
機構の歳差運動によっている。このことからジンバル機構の 歳差運動を抑制することがタッチダウンの抑制に対して有効 であることがわかる. Case BとCase CがCase Aと同じ結果と いうことから，ふれ回り振動は慣性モーメントや粘性係数に は依存しないことがわかる。一方，図7は復元係数を変化させ たCase Dの場合で，フライホイールの軌跡の範囲が小さくな り大きな変化が現れた。これより，ジンバル機構を設計する 上で最も重要なパラメータは復元係数であり，挙動に大きな 変化を与えるということがわかった。

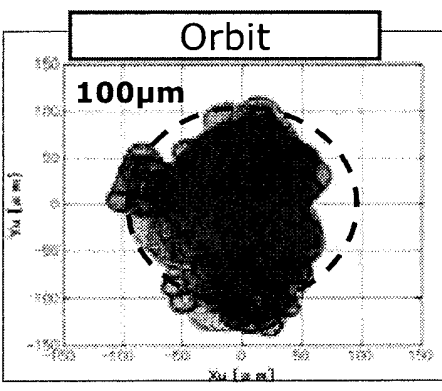

Orbit of upper

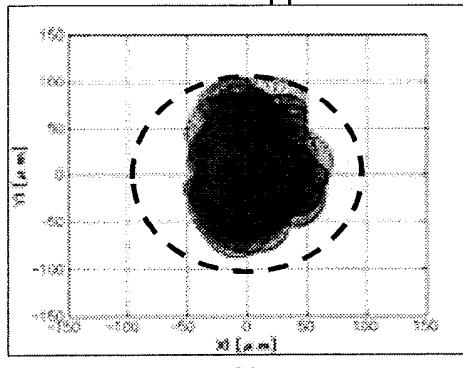

Orbit of lower

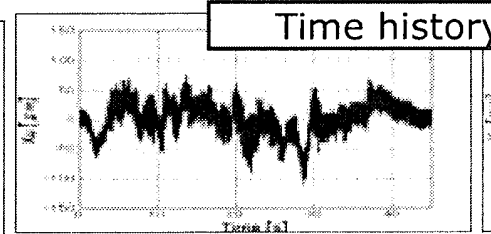

Displacement of $\mathrm{Xu}$

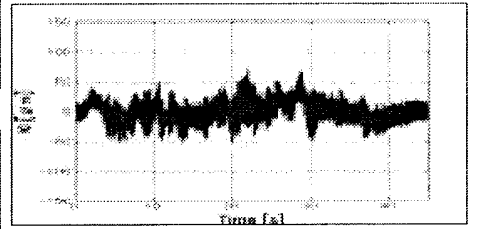

Displacement of $\mathrm{XI}$

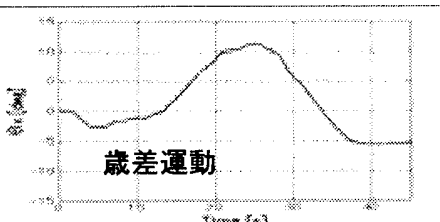

Displacement of $\Theta x$

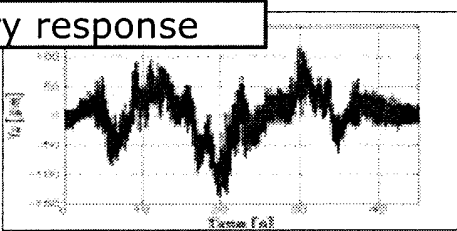

Displacement of Yu

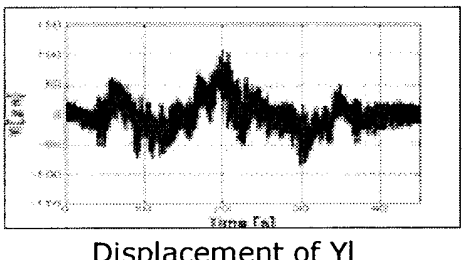

Displacement of $Y$

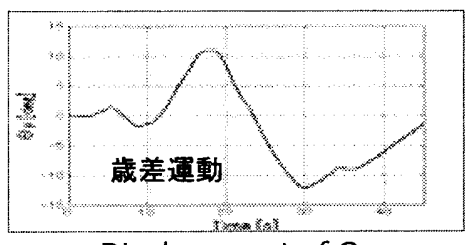

Displacement of $\Theta y$

Fig. 6 Simulated results of Case A

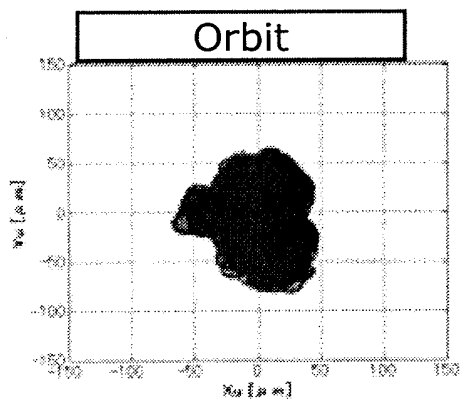

Orbit of upper

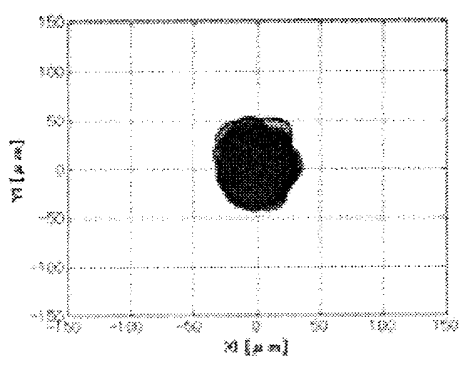

Orbit of lower

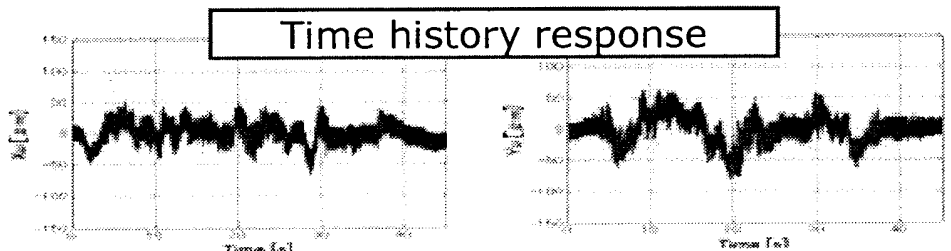

Displacement of $\mathrm{Yu}$

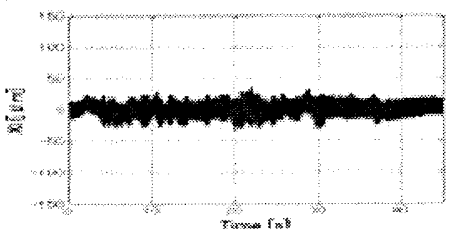

Displacement of XI

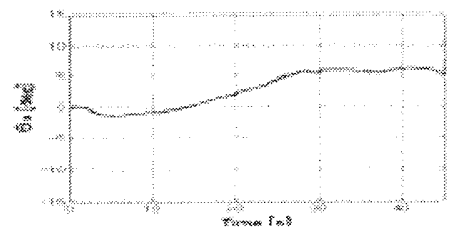

Displacement of $\Theta x$

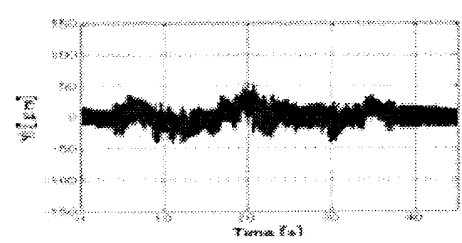

Displacement of $\mathrm{YI}$

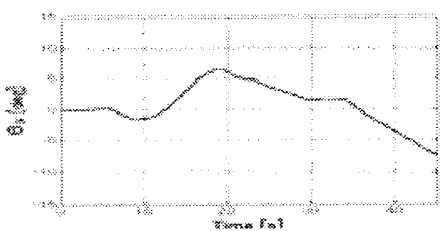

Displacement of $\Theta y$

Fig. 7 Simulated results of Case D 


\section{2 設計パラメータに関する解析的考察}

設計パラメータに対して走行シミュレーションを行った 結果, 慣性モーメントや粘性係数を変化させても力学的挙動 の変化は殆どなく, 復元係数を変化させたときの力学的挙動 に大きな変化が現れた.ここで, 歳差運動の固有振動数はCase A, B, Cの場合は27. $1 \mathrm{mHz}$, Case Dは13.6mHzであった.このこと をジンバル機構の歳差運動の固有振動数の数式解の導出を行 い確認する.ここでは導出を簡単にするためにフライホイー ルの並進運動は考えず，回転運動のみを考慮した下記のモデ ルに対して導出を行う。

$$
\left\{\begin{array}{l}
I_{r} \ddot{\theta}_{x}+I_{z} n \dot{\theta}_{y}+k \theta_{x}=-I_{r} \ddot{\Theta}_{x}-I_{z} n \dot{\Theta}_{y} \\
I_{r} \ddot{\theta}_{y}-I_{z} n \dot{\theta}_{x}+k \theta_{y}=-I_{r} \ddot{\Theta}_{y}+I_{z} n \dot{\Theta}_{x} \\
I_{\beta 0} \ddot{\Theta}_{x}+k_{\beta} \Theta_{x}=k \theta_{x} \\
I_{\alpha 0} \ddot{\Theta}_{y}+k_{\alpha} \Theta_{y}=k \theta_{y}
\end{array}\right.
$$

ここで， $\mathrm{k}$ は磁気軸受の剛性を示す．このとき特性方程式は $a_{4}\left(s^{2}\right)^{4}+a_{3}\left(s^{2}\right)^{3}+a_{2}\left(s^{2}\right)^{2}+a_{1}\left(s^{2}\right)+a_{0}=0$

ここで,

$$
\begin{gathered}
k \gg k_{\alpha}, k_{\beta} \\
I_{z} n \gg \sqrt{\left(I_{r}+I_{\alpha 0}\right) k_{\beta}+\left(I_{r}+I_{\beta 0}\right) k_{\alpha}}
\end{gathered}
$$

と仮定できるので，歳差運動の固有振動数は

$$
\omega_{p} \approx \frac{\sqrt{k_{\alpha} k_{\beta}}}{I_{z} n}
$$

図8はフライホイールの回転数を変化させたときのジンバ ル機構の固有振動数の変化であり, 式(5)の近似解と数值計算 結果を比較したものである．フライホイールの回転速度が増 加するにつれ両者は一致し, 高速回転時には式(5)の近似解よ りジンバル機構の歳差連動の固有振動数を求めることができ る.ここで, 式(5)のパラメータ構成について注目すると固有 振動数に含まれるジンバル機構の設計パラメータは復元係数 $k \alpha, k \beta$ みであり, 慣性モーメントや粘性係数などのパラ メータは含まれていない. そのためCase A, B, Cのジンバル機 構の歳差運動の固有振動数には変化がなく，応答結果にはほ とんど変化が生じないことがわかる，一方，Case Dではジン バル機構の歳差運動の固有振動数が大きく変化するので応答 結果に大きな変化が表れることがわかる.

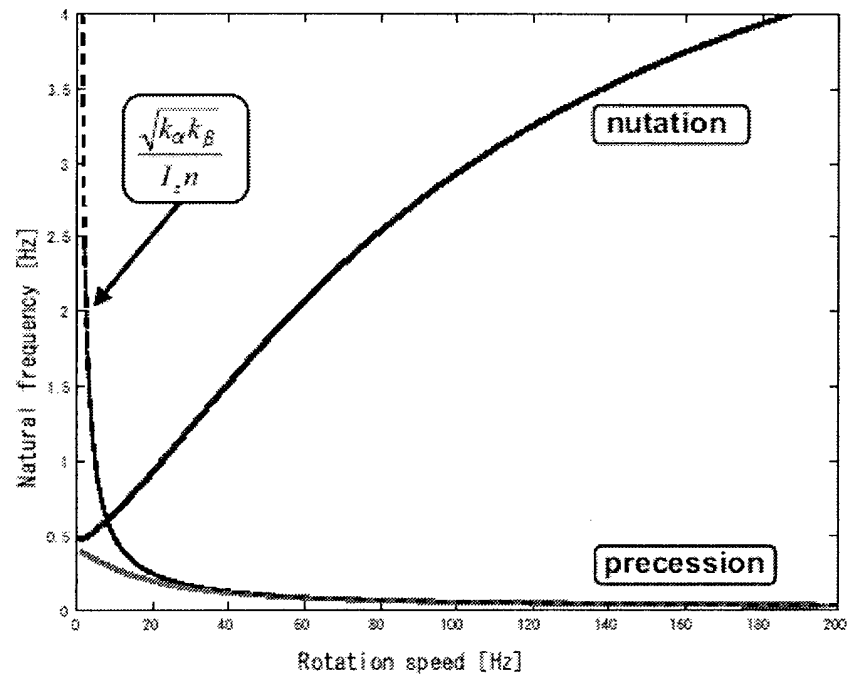

Fig. 8 Comparison of natural frequency of gimbal between numerical values and approximated values

\section{3 車載用振子型ジンバル機構の設計法}

前節をふまえて車載用に適した理想的な振子型ジンバル機 構の設計方法を考察する。ここでは主に復元係数 $k \alpha, k \beta$ の 設計方法について述べる。 $k \alpha, k \beta$ を設計する際にはジンバ ルの歳差運動の固有振動数 $\omega p$ が車体の固有振動数や加速な ど外乱の周波数帯域に千渉させないように設計する必要があ る. 特に車両の加速運動の周波数領域との干渉を防ぐ必要が ある。そのため搭載する車両の加速運動の周波数帯域を見積 もる必要がある，すなわち, ジンバル機構の歳差運動の固有 振動数は磁気軸受部分での軸荷重を低減させるために

$$
\omega_{p}<<\omega_{\min }
$$

とする必要がある. $\omega \min は$ 加速時外乱の周波数の最小值であ る. 市街地走行の15モードから加速外乱を求めると

$$
\begin{aligned}
h_{\alpha} b_{k}< & \left(I_{z} n u_{m}\right)^{2} \\
& -7.3984 \times 10^{4}\left(l_{z} n\right)^{2}
\end{aligned}
$$

これから

$$
k_{e q}<<0.0272 H
$$

3.まとめ

振子型ジンバル機構を有する磁気軸受フライホイールの運 動モデルの導出を行い導出したモデルの妥当性について検証 を行った。また，ジンバルの設計法について考察した．

\section{文献}

(1) 斉藤武雄, 小笠原弘丞, 山田昇 : フライホイールエネルギ 一貯蔵と電気自動車への応用に関する研究, 日本機械学会 論文集，70-697，pp. 2482-2489, 2004 